- In the first trial involving 86 piglets per treatment, diets containing I 8 and 20 p. Ioo crude protein, with and without fish meal, were used. The weight and mean age of the piglets at the beginnitig and at the end of the trial were the following: $9 \mathrm{~kg}$ at the age of 38 days and $28 \mathrm{~kg}$ at 73 days.

- In the second trial involving I44 piglets per treatment, a diet including $20 \mathrm{p}$. Ioo crude protein with and without fish meal was used. The weight and mean age of the animals at the beginning and at the end of the trial were the following; $9 \mathrm{~kg}$ at 38 days and $24 \mathrm{~kg}$ at 66 days.

The experimental device applied was that of the batch system. For establishing the experimental groups, the animals were chosen according to their weight at weaning and average litter weight at birth. They were weighed individually. After having established the groups (weaning) the animals were fed the starter diet ad libitum in the post-weaning room (flat-decks) where after they received the experimental diets ad libitum till the end of the experiment. The feed intake was recorded per group of piglets (6-7 animals per box).

In the two trials, there was no significant difference between the treatments as for the feed intake levels which amounted to about $\mathrm{I} \mathrm{kg} / \mathrm{day} /$ piglet.

The results of the two trials show that for a given crude protein level, the addition of fish meal to the diet did not significantly affect either the growth or the feed conversion ratio.

The great statistical value of the experitnent involving 642 piglets would most likely have evidenced a 5 p. I 00 difference of growth and feed conversion ratio between the groups, if such a difference had existed.

It may therefore be assumed that when the rearing conditions permit to obtain high performances in the weaned piglets (more than $500 \mathrm{~g} / \mathrm{day}$ ), an increase in the productivity depends most likely on an increase in the supply of crude protein, the advantage of using fish meal, even of good quality, being illusory.

\title{
Processing technology of early weaning feeds for piglets: influence of the physical form (meal or pellets) and the pelleting conditions on the utilization of diets based on barley or maize
}

\author{
P. QUEMERE (1), G. BERTRAND ( $\left.{ }^{(}\right)$, J. MI. PEREZ $\left({ }^{2}\right)$, B. SEVE $\left({ }^{2}\right)$ \\ (1) S.E.R.E.P., Institut Supérieur Agricole, 60026 Beauvais (France) \\ (2) Station de Recherches sur l'Élevage des Porcs, \\ Centre national de recherches zootechniques, I.N.R.A., \\ $7835^{\circ}$ Jouy-en-Josas (France)
}

Three hundred sixty piglets were used to study the influence of the physical form of the feed (maal, pellets obtained by $d r y$ or steam pelleting) on the performance of the piglets after weaning. The possible interactions with the kind of cereal used (barley or maize), the initial weight of the animals ("light " and "heavy " at weaning) and their age (Ist and 2 nd age feeding) were also investigated. Pre starter and starter feeds were isonitrogenous and iso-lysine. The pressing conditions of the pellets, the particle size of the initial meal, the variation in the inletoutlet temperature of the die, the rate per hour of the press as well as the final technological characteristics of the pellets, were described. Use of steam resulted in a harder, more durable pellet and a higher rate per hour of the press than the dry treatment. It was not possible in any case to establish a relationship between hardness measures and feed intake level. However the intake of pellets including barley was lower (- I2 p. IOO) than that of the corresponding meal. The growth rate of the piglets was little affected by the physical form of the feeds based on barley, whereas an $8 \mathrm{p}$. I oo improvement was observed with the dry pelleting of feeds based on maize. The pressing treatment affected in particular the feed efficiency, the effects $(+19$ to $+23 \mathrm{p}$. IOO) being more marked in the young piglets (from the age of 20-25 days, with the Ist age feed) and light ones $(5.1$ to $5.4 \mathrm{~kg})$. On the basis of the whole experimental period, dry pelleting appeared to be more advatitageous ( $+\mathrm{I}_{5}$ and I I p. Ioo, respectively with barley and maize) than steam pressing $(+8$ and +6 p. I0o). Likewise, the cereal which was the least efficient in form of meal (barley) was the best valorized by pelleting. The efficiency of the diets based on maize was $7 \mathrm{p}$. I oo higher than that of the diets based on barley probably because of a higher 
digestible energy concentration. However, this effect only appeared during the 2 nd age period, barley being as efficient as maize immediately after weaning (Ist age feed).

Pelleting of weaning feeds improving the feed efficiency also reduced the frequency of diarrhoea and therefore seemed to be very favourable in particular for the youngest and lightest animals at weaning.

\title{
Study of some factors of variation of the digestive transit in pregnant sows (crude fibre level and constipation)
}

\author{
M. PALISSE, M. COLIN, Y. MAURY \\ Sanders S.A., I7, quai de l'Industrie, 9I26o Athis-Mons (France)
}

Use of high energy diets with low crude fibre levels was studied in pregnant sows. The experiment showed the existence of:

- a relationship between the crude fibre level and the transit rate owing to the utilization of markers (chromium oxide);

- an increase in the apparent digestibility of the diet after reduction of the cellulose level.

\section{Comparative utilization of the three French barley varieties by the growing-finishing pig}

\author{
J.-P. BOUARD ( $\left.{ }^{1}\right)$, J. CASTAING $\left({ }^{2}\right)$, M. LEUILLET $\left({ }^{1}\right)$, J. Y. TIRILLY $\left({ }^{1}\right)$ \\ (1) Institut Technique des Céréales et des Fourrages, \\ 8, avenue du Président-Wilson, 75116 Paris \\ (2) Association Générale des producteurs de Maïs, \\ I, place de Lestapis, 64000 Pau (France)
}

A comparison was made in the bacon pig between three types of barley: spring barley, tworow winter barley and six-row winter barley and an energy rich cereal, wheat (trial $\mathrm{I}$ during the finishing period) as well as maize (trial 2 during the growing-finishing period). The cereals were supplemented with soybean meal so that the protein supply be not limitating.

The digestible energy value of the barleys was estimated according to Henry and Bourdon's proposals by taking into account their crude fibre and moisture conterits assuming that, in terms of energy, 2.I 3 points water equal I point crude fibre. In each trial the animals received daily the same digestible energy supply, the feed restriction schedule being modulated according to the energy concentration of the diets.

In both trials we obtained comparable growth performances with the different diets, $665 \mathrm{~g}$ and $688 \mathrm{~g} / \mathrm{d}$, respectively. The energy ratios were also very close whatever the control cereal or the type of barley used, II.39 Mcal $/ \mathrm{kg} \pm 0.22$ and $9.90 \mathrm{Mcal} / \mathrm{kg} \pm 0 . \mathrm{I} 2$.

This relative steadiness of the energy ratio confirmed our results atid the information from literature. The feed conversion ratios ( $\mathrm{kg}$ feed $/ \mathrm{kg}$ live weight gain) increased therefore with the crude fibre content of the barley variety used, the discrepancy between energy cereals and barleys reaching to $\mathrm{p}$. Ioo on an average at the expense of the latter.

Thus, the correction proposed by Henry and Bourdon seems to be interesting. It is based upon the variation of the etiergy apparent digestibility coefficient according to the crude fibre level. Thus using as a basis the digestible energy implies a constant gross energy value whatever 